\title{
PALAEOMAGNETISM OF SOUTH AMERICAN AND AFRICAN ROCKS AND THE AGE OF THE SOUTH ATLANTIC
}

\author{
JUAN F.A. VILAS and DANIEL A. VALENCIO
}

\begin{abstract}
The late Palaeozoic polar path, common to the South American-African block, defines a continuous shift of about $60^{\circ}$ from the Late Carboniferous to the Middle Permian. During this episode that block moved away from the South pole. In either early Middle or late Early Permian time, such movement stopped and a quasi-static period started for the South American-African block which lasted up to the Jurassic.

$A$ new and reversible polar shift (about $35^{\circ}$ ) relative to the South American-African block started in either late Jurassic or early Early Cretaceous time; previous palaeomagnetic studies did not recognize this Early Cretaceous polar shift common to the South AmericanAfrican block. In late Early Cretaceous time such movement stopped for South American and a quasi-static period started for this continent, which lasted up to the late Late Cretaceous. Palaeomagnetic data for Africa suggest that the Cretaceous polar shift was still present for this continent in Late Cretaceous time. This suggests that: i) South America and Africa were joined by their Atlantic margins up to the Early Cretaceous; and ii) the separation of these continents and the origin of the South Atlantic took place in late Early Cretaceous time (after the Serra Geral and Kaoko basaltic magmatism). However, the palaeomagnetic data do not rule out the possibility that the initial rifting in the South AmericanAfrican block has occurred in Early Cretaceous time.
\end{abstract}

RESUMO: A trajetória polar do Paleozóico Superior, comum ao bloco América do SulÄfrica, define uma deriva contínua de aproximadamente $60^{\circ}$, do Carbonífero Superior ao Permiano Médio. Durante esse episódio, o bloco afastou-se do Pólo Sul. No Permiano Médio, tal movimento teria cessado e teria começado um período quase estático para o bloco América do Sul-Âfrica, que perdurou até o Jurássico.

Nova deriva polar reversível (aproximadamente $35^{\circ}$ ), relativa ao bloco América do SulĀfrica, iniciou-se no Jurássico Superior ou bem no início do Cretáceo; estudos paleomagnéticos anteriores não haviam reconhecido essa deriva polar no Cretáceo Inferior. No final do Cretáceo Inferior, esse movimento cessou para a América do Sul e iniciou-se um período quase estático para este continente, que perdurou até o Cretáceo Superior. Dados paleomagnéticos para a África sugerem que a deriva polar cretácica ainda se fazia presente para este continente no Cretáceo Superior. Isso sugere que: i) A América do Sul e a África estiveram unidas pelas suas margens atlânticas até o Cretáceo Inferior; e ii) a separação desses continentes e a Origem do Atlântico Sul teve lugar no Cretáceo Inferior (após o magmatismo basáltico do Kaoko e da Serra Geral). Contudo, os dados paleomagnéticos não eliminam a possibilidade que o processo inicial no bloco América do Sul-África tenha ocorrido no Cretáceo Inferior.

INTRODUCTION Late Palaeozoic and Mesozoic palaeomagnetic poles for South America and Africa are used to define the movements associated wih the formation of the South Atlantic. The palaeomagnetic data recently presented for Cretaceous

Departanento de Ciências Geológicas, Facultad de Ciencias Exactas y Naturales, Universidad de Buenos Aires, Ciudad Universitaria de Nuñez, Pabellón 2, Buenos Aires, Argentina. 
rocks from South America (Valencio, 1972; Opdyke and MacDonald, 1973; Linares and Valencio, 1975; Mendia, 1976; Vilas, 1976; Valencio and Vilas, 1976; Pacca and Hiodo, 1976 and Valencio et al., 1977) and Africa (Raja and Vise, 1973; Bardon et al., 1973; Shazly and Krs, 1973; Schult, 1973; Gidskehaug et al., 1975; Hailwood, 1975 and McElhinny and Brock, 1975) suggest a new chronology for the episodes, associated with the origin of the South Atlantic. This chronology is compared with that suggested by the Cretaceous faunas from South America and Africa (Hallam, 1967; Reyment, 1969 and Reyment and Tait, 1972) and the magnetic lineations recorded in the South Atlantic (Larson and Ladd, 1973).

In the following items are frequently used the terms age group and time group; therefore we consider useful to define them. An age group is a group formed by poles of the same age; a time group is a group formed by poles of different ages and represents a specific length of time, during which the pole remained essentially stationary (quasi-static interval, Valencio and Vilas, 1972).

AVAILABLE DATA Late Palaeozoic and Mesozoic palaeomagnetic poles for South America The Late Palaeozoic apparent polar path for South America has been lately analyzed in several papers (Valencio et al., 1975a and 1975b and Valencio and Vilas 1976). More recently; a detailed study of red beds from the Middle (Late Palaeozoic age) and Upper Sections (Early Triassic age) of Paganzo Group, exposed near Paganzo Village (Argentina) has given two palaeomagnetic poles which supersede those presented by Thompson (1972) for the same rocks (Valencio et al. , 1977). The apparent polar path for South America, between the Late Carboniferous and either the early Middle or late Early Permian, defined in this paper, is shown in Figure 1 (solid curve). Basically this path is similar to that presented in previous papers; however, it is now accepted an older age for the begining of the quasistatic period (time group SAP-J, Table I), which put and end to the Late Carboniferous polar shift.

Seven palaeomagnetic poles have been recently presented for Cretaceous rocks from South America (see references in Introduction). The Cretaceous palaeomagnetic poles for South America form an age group of early Early Cretaceous age and a

Table I - Mean positions of groups formed by palaeomagnetic poles for South America and Africa

\begin{tabular}{|c|c|c|c|c|c|c|c|c|}
\hline W & Name & Group & Age & $\begin{array}{l}\text { Latitude } \\
\left({ }^{\circ}\right) \text { South }\end{array}$ & $\begin{array}{l}\text { Longitude } \\
\left(^{\circ}\right) \text { East }\end{array}$ & $\mathrm{N}$ & $\begin{array}{l}\alpha_{95} \\
\left(^{\circ}\right)\end{array}$ & $\mathrm{k}$ \\
\hline \multirow{4}{*}{$\begin{array}{c}\text { South } \\
\text { America }\end{array}$} & SAK1-ư & Time Group & late Early to Late Cretaceous & 87 & 194 & 4 & 5 & 278 \\
\hline & SAKl & Age Group & Early Cretaceous & 78 & 27 & 4 & 7 & 190 \\
\hline & SAP·J & Time Group & $\begin{array}{l}\text { late Early Permian to Middle } \\
\text { Jurassic }\end{array}$ & 82 & 244 & 14 & 4 & 90 \\
\hline & $\mathrm{SACu}$ & Age Group & Late Carboniferous & 63 & 348 & 5 & 8 & 89 \\
\hline \multirow{7}{*}{ Africa } & AfKu & Age Group & Late Cretaceous & 61 & 47 & 3 & 8 & 238 \\
\hline & AfK & Age Group & younger than Early Cretaceous & & & & & \\
\hline & & & but older than Late Cretaceous & 76 & 27 & 3 & 5 & 609 \\
\hline & AfK 1 & Age Group & Early Cretaceous & 61 & 81 & 2 & 5 & 2147 \\
\hline & AfKle & Age Group & early Early Cretaceous & 46 & 79 & 2 & 26 & 95 \\
\hline & AfPu-J & Time Group & Late Permian to Jurassic & 65 & 75 & 20 & 4 & 66 \\
\hline & AfPC & Age Group & Permocarboniferous & 62 & 37 & 3 & 8 & 213 \\
\hline
\end{tabular}




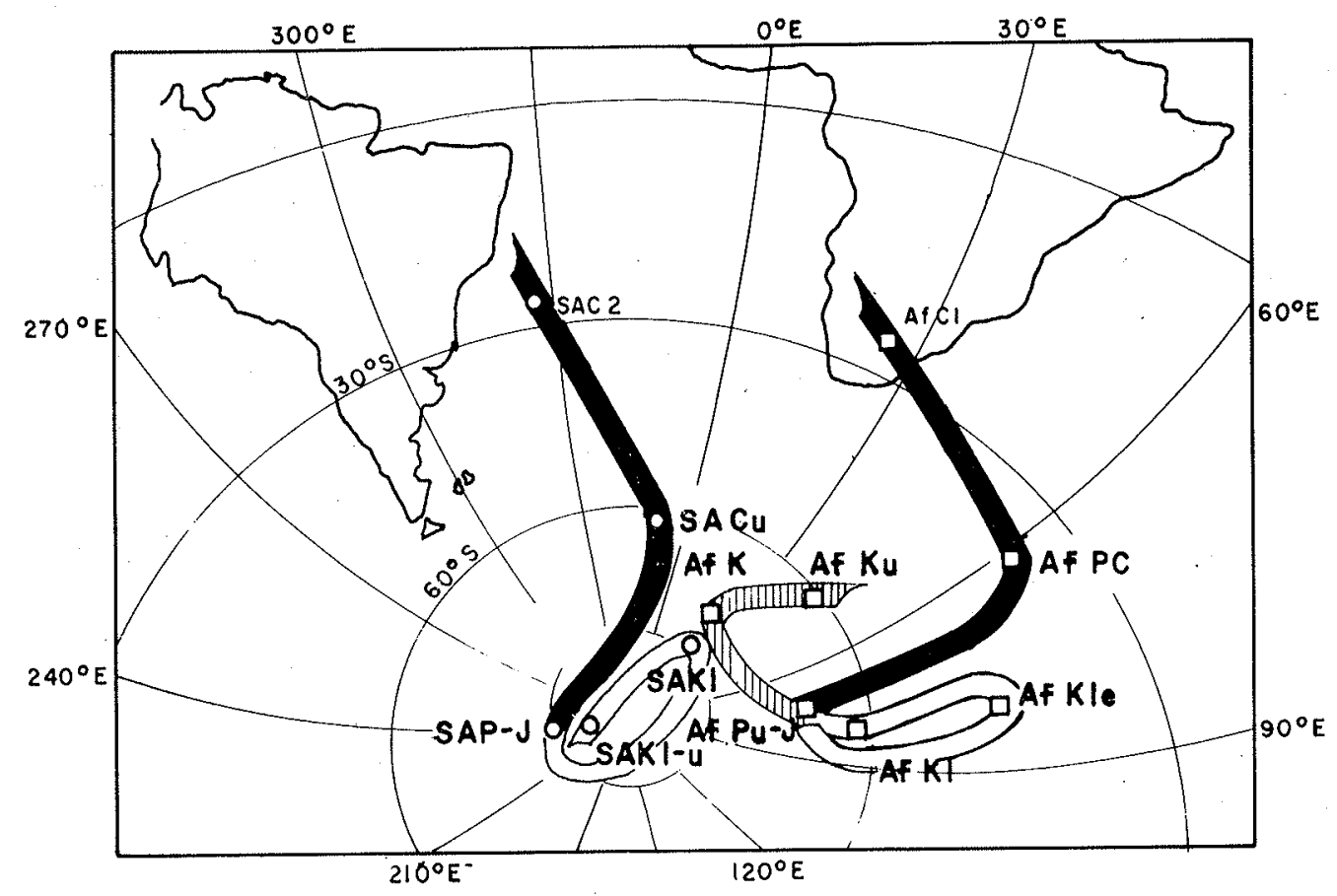

Figure 1 - Late Palaeozoic-Late Cretaceous sections of the polar wandering curves of South America and africa. $O$, South American poles; $\square$ African poles. $S A C_{2}$ is the palaeomagnetic pole por the Moscovian Taiguati Formation; $\mathrm{AfC}_{1}$ is the palacomagnetic pole for the Carboniferous Dwyka Formation (McElhinny and Opdyke, 1968). Other references in Tab. I.

time group of late Early Cretaceous to Late Cretaceous age; the mean positions of these groups, SAK 1 and SAK1-u, respectively, are given in Tab. I and shown in Fig. 1. Groups SAP-J, SAK1 and SAK1-u are formed by palaeomagnetic poles, computed on basis of the stable remanence of rocks collected in different areas of South America. That implies that the geomagnetic field was dipolar and geocentric in those times and that no relative movements have occurred between these collecting areas. Therefore, the apparent polar defined by the mean position of groups SAP-J, SAK 1 and SAK1-u, may be attributable to two possible causes: i) an episode of reversible motion of South America in Early Cretaceous times, or ii) a temporary excursion of the geomagnetic pole relative to a stationary South America. As the geomagnetic field was dipolar and geocentric in those times, the second possible cause would imply that the geomagnetic field was not axial during million of years; on the other hand, given its global range, the Early Cretaceous temporary excursion of the geomagnetic pole should have been recorded in Cretaceous rocks of all the other continents. We shall show that a similar apparent polar path has been recorded in Cretaceous rocks from Africa. However, the cretaceous palaeomagnetic poles of the other continents do not show such excursion of the geomagnetic field. Therefore, it seems to us that the Cretaceous polar path defined by the South American palaeo- 
magnetic poles represents an episode of reversible motion of this continent (Valencio et al., 1977). That is, they define a rapid apparent polar wander relative to South America which started in either Late Jurassic or in early Early Cretaceous time. In late Farly Cretaceous time such polar wander stopped and a quasi-static period started for this continent, which lasted up to the late Late Cretaceous (SAK1-u).

Fig. 1 shows the rapid polar shift relative to South America, which spanned the time from the Moscovian $\left(\mathrm{SAC}_{2}\right)$ to either the early Middle or late Early Permian (SAP-J) (solid curve). In this episode, South America moved away from the South pole. In either early Middle or late Early Permian time, such movement stopped and a quasi-static period started for South America, which lasted up to the Middle Jurassic (SAP-J). The early Cretaceous apparent polar shift, relative to South America mentioned before, put and end to this quasi-static period. Fig. 1 shows this early Cretaceous polar shift (white curve); in late Early Cretaceous time, this polar shift stopped and a new quasi static period started for South America, which lasted up to the late Late Cretaceous (SAK1-u).

Late Palaeozoic and Mesozoic palaeomagnetic poles for Africa Palaeomagnetic poles for Lower Permian (Hamzeh, 1973, and Daly and Pozzi, 1976), PermoTriassic (Rocha Campos et al., 1978), Triassic (Hailwood, 1975; McElhinny and Brock, 1975 and Daly and Pozzi, 1976) and Cretaceous (see references in Introduction) rocks from Africa have been recently presented. The Lower Permian palaeomagnetic poles, presented by Daly and Pozzi and Hamzeh, form an age group with the Upper Carboniferous-Lower Permian palaeomagnetic pole for the Ecca Red beds (Opdyke, 1964). We have not the palaeomagnetic data on basis of which Hamzeh's pole was computed and, therefore, we are not able to evaluate whether it may be used for palaeogeographic interpretation. The mean position of the Permocarboniferous age group for Africa (AfPC), given in Tab. I, does not include the Hamzeh's pole.

Hailwood (1975) has suggested that the African Triassic palaeomagnetic poles show an elongate distribution "which trend in a westerly direction away from the mean Mesozoic position". This interpretation is based in the positions of two poles: one presented by Nairn (1964) and other one (Issaldain dolerites, Middle Triassic) presented by Hailwood. We think that the first of these poles is not useful for sound interpretations: it was computed on basis of the palaeomagnetic study of five samples collected at two sites and its $\alpha_{95}$ is unknown. Fig. 2 shows the available Triassic palaeoniagnetic poles for Africa, which satisfy a minimun criterion of confidence; the only palaeomagnetic pole which suggests an elongated distribution is that of Issaldain dolerites; the others show a fairly good fisherian distribution. Therefore, it seems to us that there is not evidence for an elongated distribution of the Triassic African poles and that the position of the Issaldain pole may be a consequence of local remagnetization in Tertiary or Recent times.

Fig. 3 shows the positions of the Permo-Triassic (Rocha Campos et al., 1977), Triassic (Fig. 2) and Jurassic (Valencio and Vilas, 1976) palaeomagnetic poles for Africa; Valencio and Vilas, 1976, and Rocha Campos et al., 1977, have suggested that they form a time group reflecting a quasi-static period (AfPu-J, Tab. I).

Valencio et al., 1977, have suggested that the Cretaceous palaeomagnetic poles for Africa form four groups of early Early Cretaceous (AfKle), Early Cretaceous (AfK1), younger than Early but older than Late Cretaceous (AfK) and Late Creta- 


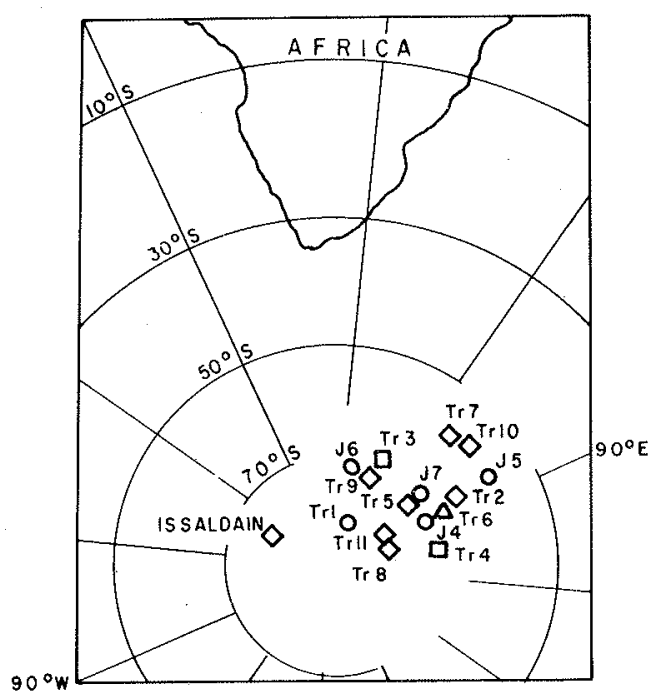

Figure 2 - Palaeomagnetic poles for Africa assigned to the Triassic which satisfy a minimum criterion of confidence; $\Delta$, Lower Triassic; $\diamond$, Middle Triassic; $\square$, Upper Triassic and $O$, Upper Triassic-Lower Jurassic. (AfTr 1 - AfTr ${ }_{4}$ and $\mathrm{AfJ}_{4}-\mathrm{AfJ}_{7}$,

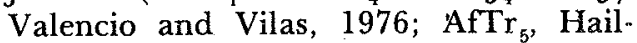
wood, 1975; AfTr $_{6}$, McElhinny and Brock, 1975, and $\operatorname{AfTr}_{7}=\operatorname{AfTr}_{11}$, Daly and Pozzi, 1976). The palaeomagnetic pole for the Tichka sediments, Morocco $\left(68^{\circ}\right.$ South $87^{\circ}$ East, Hailwood, 1975) has not been included given that its $\alpha_{95}$ is greater than $20^{\circ}$

Figure 3 - Permo-Triassic $(\Delta)$, Triassic $(\diamond)$ and Jurassic $(O)$ palaeomagnetic poles for Africa. (AfPTr ${ }_{1}$, Rocha Campos et al., 1977; $\mathrm{AfJ}_{1}-\mathrm{AfJ}_{3}$ and $\mathrm{AfJ}_{8}$, Valencio and $\mathrm{Vi}$ las, 1976; other references as in Fig. 2)

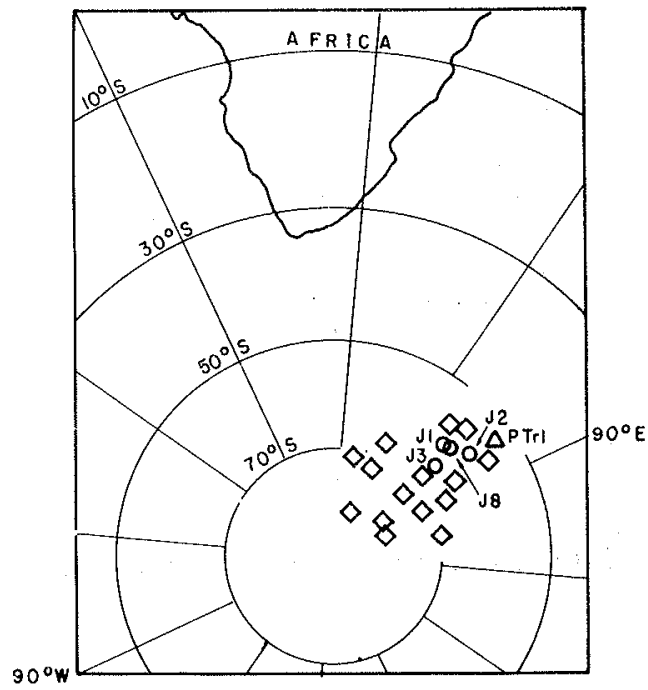

ceous (AfKu) age. The mean positions of these age groups (Tab. I, Fig. 1) define a rapid Cretaceous polar shift relative to Africa, which started in either Late Jurassic or very Early Cretaceous time. Part of this polar shift, that occurred in Early Cretaceous time and shown by the white curve in Fig. 1, is similar to the Early Cretaceous apparent polar shift of South America; following the same reasoning for this continent, we interpret that the Early Cretaceous polar shift represents an episode of reversible motion of Africa.

Fig. 1 shows the Carboniferous-Late Cretaceous section of the apparent polar wandering curve for Africa. Note the rapid late Palaeozoic polar shift (solid curve); in this episode Africa moved away from the South pole. In Permian time a quasistatic period began for Africa, which lasted up to the Late Jurassic (AfPu-J). The Cretaceous polar shift (white and striped curves) put an end to that quasi-static period; Fig. 1 shows that this polar shift was still present in Late Cretaceous time. 


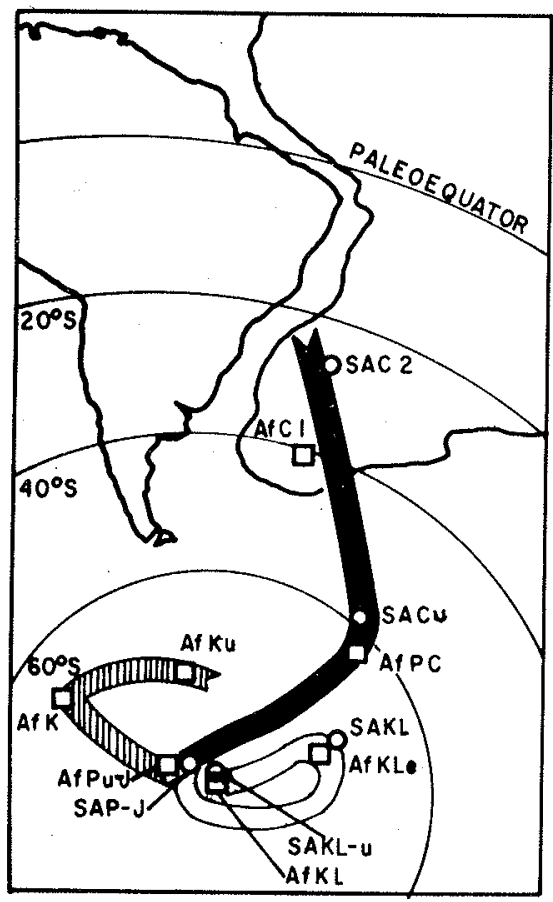

Figure 4 - Palaeomagnetic reconstruction of the positions of South America and Africa for the late Palaeozoic, Triassic, Jurassic and Lower Cretaceous. References in the text. Symbols as in Fig. 1

DISCUSSION Fig. 4 shows that by a superposition, of the Late Palaeozoic (solid curves) and Early Cretaceous (white curves) sections of the apparent polar wandering curves of South America and Africa, the two continents are brought into adjacent positions; it can be noted the coincidence of the mean polar positions of: i) the age groups SACu and AfPC; ii) the time groups SAP-J and AfPu-J; iii) the age groups SAKl and AfKle, and iv) the time group SAK1-u and the age group AfK1. This suggests that South America and Africa, joined by their Atlantic margins, moved away from the South pole during the late Carboniferous and early Permian; this rapid displacement $\left(60^{\circ}\right)$ stopped in either early Middle or late Early Permian time when a quasi-static period started for the South American-African block which lasted up to Late Jurassic. A new and reversible polar shift common to this block $\left(35^{\circ}\right)$ started in Late Jurassic or Early Cretaceous time and lasted up to the late Early Cretaceous. In this time, a quasi-static period started for South America, which lasted up to Late Cretaceous (SAK1-u); on the other hand, the Cretaceous polar shift relative to Africa was still present in Late Cretaceous time. This suggests that the opening of the South Atlantic took place in late Farly Cretaceous time after the Serra Geral basaltic magmatism.(Gidskehaug et al., 1975, Valencio and Vilas, 1976, and Pacca and Hiodo, 1976). However, given that the comparison of positions of palaeomagnetic poles does not enable to define small relative continental movements, we must accept that the initial rifting in the South Atlantic could have started during the Serra Geral magmatism.

Reyment and Tait, 1972, have indicated that N.E. Brazil and Gabon had been basins of non marine sedimentation from the Late Palaeozoic to the Neocomián; particularly, in Neocomian time these areas were parts of a large freshwater 
lake. It seems to us that this lake could have been formed during a vast subsidence episode in the South American-African block associated with a former phase of the opening of the South Atlantic. This zone of subsidence was associated with hot spots; emplacement of igneous rocks above these hot spots was followed by rifting and continental separation with accretion of oceanic crust. Small horizontal relative movements between South America and Africa occurred during the initial rifting; that explains why this is not defined in palaeogeographic reconstructions based on the comparison of positions of palaeomagnetic poles. The Serra Geral basaltic magmatism would have occurred during that initial rifting. This interpretation agrees with the similarity of the Lower Cretaceous faunas from South America and Africa (Hallan, 1967, Reyment, 1969, and Reyment and Tait, 1972) and the age assigned to the magnetic lineations recorded in the South Atlantic (Larson and Ladd, 1973). South America and Africa began to drift apart in late Early Cretaceous time: this drift has been recorded in the remanence of late Lower and Upper Cretaceous rocks of these continents and is supported by the Aptian salt deposits of Gabon and N.E. Brazil.

Acknowledgements The authors wish to think the Universidad de Buenos Aires and the Consejo Nacional de Investigaciones Científicas y Técnicas of Argentina for the financial support which enable the work described to be carried on.

\section{REFERENCES}

BARDON, C., BOSSER, A., HAMZEH, R., ROLLEY, J.P. and WESTPHAL, M., 1973. Etude paléomagnetique de formations volcaniques du Crétacé inférieur dans l'Atlas de Beni Mellal (Maroc). C.R. Acad. Sci. Paris (277), Série D, pp. 2141-2144.

DALY, L., and POZZI, J.P., 1976 Resultats paléomagnétiques du Permien Inférieur et du Trias Morocain; comparaison avec les données Africaines et Sud Americaines. Earth Planet. Sci. Let., 29: 71-80.

GIDSKEHAUG, A., CREER, K.M. and MITCHELL, J.G., 1975. Palaeomagnetism and KAr ages of the Southwest African basalts and their bearing on the time of initial rifting of the South Atlantic ocean. Geophys. J. Roy. Astr. Soc., 42: 1-19.

HAILWOOD, E.A., 1975. The palaeomagnetism of Triassic and Cretaceous rocks from Morocco. Geophys. J. Roy. Astr. Soc., 41: 219-235.

HALLAM, A.,. 1967. The bearing of certain palaeozoogeographic data on continental drift. Palaeoec. Palaeod. 3: 201-204.

HAMZEH, R., 1973. Thèse de spécialité, Strasbourg.

LARSON, R.L. and LADD, J.W., 1973. Evidence of the opening of the South Atlantic in the early Cretaceous. Nature, 246: 209-211.

LINARES, E. and VALENCIO, D.A., 1975. Palaeomagnetism and K-Ar ages of the Río de Los Molinos dikes, Province of Córdoba, Argentina. Jour. Geophys. Res., 80: 33153321.

MCELHINNY, M.W. and BROCK, A., 1975. A new palaeomagnetism result from east Africa and estimates of the Mesozoic palaeoradius. Earth Planet. Sci. Let., 27: $321-328$.

McELHINNY, M.W. and OPDYKE, N.D., 1968. Paleomagnetism of some Carboniferous glacial varves from Central Africa. J. Geophys. Res., 73: 689. 
MENDÍA, J.E., 1976. Palaeomagnetic study of alkaline volcanites from Almafuerte, Province of Córdoba, Argentina. Geophys. J. Roy. Astr. Soc., in press.

NAIRN, A.E.M., 1964. Palaeomagnetic measurements on Karroo and post-Karroo rocks, a second progress report. Overseas Geol. Mineral Resources, Great Brit., 9: 302-320.

OPDYKE, N.D., 1964. The palaeomagnetism of the Permian redbeds of South west 'Tanganyika, J. Geophys. Res., 69: 2477.

OPDYKE, N.D. and MacDONALD, W.D., 1973. Palaeomagnetism of late Cretaceous. Poços de Caldas Alkaline Complex, Southern Brazil. Earth Planet. Sci. Let., 18: 37-44.

PACCA, I.G. and HIODO, F.H., 1976. Paleomagnetic analysis of Mesozoic Serra Geral Basaltic lava flows in Southern Brazil. Symposium on continental margins of Atlantic type, São Paulo, Brazil, 1975. An. Acad. Bras. Ciênc., 48(Suplem.): 207-214.

RAJA, P.K.S. and VISE, J.B., 1973. Palaeomagnetism of the Tororo Ring Complex, S.E. Uganda. Earth Planet. Sci. Let., 19: 438-442.

REYMENT, R.A., 1969. Ammonite biostratigraphy, continental drift and oscillatory transgressions. Nature, 224: 137-140.

REYMENT, R.A. and TAIT, E.A., 1972. Biostratigraphical dating of the early history of the South Atlantic Ocean. Philosophical Transact. Roy. Soc. London, 264: 55-95.

ROCHA CAMPOS, A.C, VALENCIO D.A., and PACCA, I.G., 1978. Palaeomagnetism of the Cassange Series, Karroo System Angola. An. Acad. Bras. Ciênc, 50: 353-364.

SCHULT, A., 1973. Palacomagnetism of Upper Cretaceous volcanic rocks in Sicily. Earth Planet. Sci. Let., 19: 97.

SHAZLY, E.M. and KRS, M., 1973. Paleogeography and.paleomagnetism of the Nubian Sandstone, Eastern Desert of Egypt. Geol. Rundsch, 62: 212.

THOMPSON, R., 1972. Paleomagnetic results from the Paganzo Basin of North-West Argentina. Earth Planet. Sci. Let., 15: 145-156.

VALENCIO, D.A., 1972. Palaeomagnetism of the Lower Cretaceous volcanites Cerro Colorado Formation of the Sierra de los Cóndores Group, Province of Córdoba, Argentina. Earth Planet. Sci. Let., 16: 370-378.

VALENCIO, D.A. and VILAS, J.F., 1972. Palaeomagnetism of Late Palaeozoic and Early Mesozoic rocks of South America. Earth Planet. Sci. Let., 15(1): 75-85.

VALENCIO, D.A. and VILAS, J.F., 1976. Sequence of the continental movements occurred prior to and after the formation of the South Atlantic. Symposium on continental margins of Atlantic type, São Paulo, Brazil, 1975. An. Acad. Bras. Ciênc., 48(Suplem.): 377-386.

VALENCIO, D.A., MENDÍA, J.E. and VILAS, J.F., 1975a. Palaeomagnetism and K-Ar ages of Triassic igneous rocks from the Ischigualasto-Ischichuca Basin and Puesto Viejo Formation, Argentina. Earth Planet. Sci. Let., 26: 319-330.

VALENCIO, D.A., MENDÍA, J.E., GIUDICI, A. and GASCON, J.O., 1977. Palaeomagnetism of the Cretaceous Pirgua Subgroup (Argentina) and the age of the opening of the South Atlantic, Geophys. J. Roy. Astr. Soc., 51(1): 47-58.

VALENCIO, D.A., ROCHA CAMPOS, A.C. and PACCA, I.G., 1975b. Palaeomagnetism of some sedimentary rocks of the late Palaeozoic Tubarão and Passa Dois Group from the Paraná Basin, Brasil. Rev. Brasileira Geociências, 5: 186-197.

VALENCIO, D.A., VILAS, J.F. and MENDÍA, J., 1977. Palaeomagnetism of the Middle and Upper Sections of the Paganzo Group (Argentina) and the Correlation of Upper Palaeozoic-Lower Mesozoic rocks. Geophys. J. Roy. Astr. Soc., 51(1): 59-74.

VILAS, J.F,, 1976. Palaeomagnetism of the Lower Cretaceous Sierra de los Cóndores Group, Province of Córdoba, Argentina. Geophys. J. Roy. Astr. Soc. 46: 295-305. 